\author{
Bondarenko O. S., \\ $P h D$. in Law, \\ Senior Lecturer at the Department of Criminal Law and Judiciary \\ Educational-Scientific Institute of Law \\ of the Sumy State University
}

\title{
CRIMINAL LEGAL CHARACTERISTICS OF CORRUPTION CRIMINAL OFFENSES IN THE FIELD OF ECONOMIC ACTIVITY ${ }^{1}$
}

Summary. The article is devoted to an important topic - the criminal-legal characteristics of corruption criminal offenses in the sphere of economic activity. The author emphasizes that corruption is a destructive socio-economic phenomenon. The most dangerous manifestations of it are corruption criminal offenses. It is possible to classify corruption criminal offenses according to several criteria. One of them is an object of a criminal offense. On the basis of this criterion it is possible to single out corruption criminal offenses in the sphere of economic activity. According to Section VII of the Special Part of the Criminal Code of Ukraine, the legislator includes misuse of budget funds, budget expenditures or granting of budget loans without established budget allocations or with their excess (Article 210 of the Criminal Code of Ukraine).

The generic object of this criminal act is public relations, which ensure the legitimate functioning of the budget system of Ukraine in terms of expenditures or loans, and additional direct - the rights and freedoms of citizens, relations in the sphere of official activities, the authority of public authorities and more. The item of the analyzed corruption criminal offense is budget funds, funds included in the state budget and local budgets, regardless of the source of their formation, in large and especially large amounts.

The objective side of the analyzed action is the use of state or local budgets contrary to the purpose defined for these funds by the relevant budgets and estimates of revenues and expenditures: the use of targeted budget funds for another purpose, i.e. the financing of some expenditures at the expense of other items of expenditure (for example, the financing of production at the expense of funds intended for the payment of wages).

Only an official authorized to dispose of budget funds may be the subject of the analyzed criminal offense. These are primarily responsible officials of enterprises, institutions and budget organizations (managers of budget funds, heads of state executive bodies, heads of departments of ministries, departments, mayors of Kyiv and Sevastopol, regional, district, city state administrations and their deputies, rural, township and mayors, officials of local financial bodies, heads of budgetary institutions). From the subjective point of view, this criminally illegal act can be committed only in the form of direct intent.

In contrast to the legislator, who among the corruption criminal offenses in the field of economic activity includes only misuse of budget funds, budget expenditures or loans from the budget without established budget allocations or with their excess, we are convinced that the list of such acts is much wider and necessary include money laundering.

' Робота виконана в рамках проєкту № $0120 \mathrm{U} 100474$ «Розробка методики взаємодії правоохоронних органів України щодо протидії легалізації злочинних доходів» 0120U100474.
Based on the analysis, it is concluded that firstly it is necessary to supplement the note to Art. 45 new criminal offenses. Secondly, it is necessary to amend Art. 209 of the Criminal Code of Ukraine, supplementing it with the instruction on implementation of the criminally illegal actions specified by h. 1 by the official by abuse of office. We propose to set out Part 2 of Art. 209 of the Criminal Code of Ukraine in the following wording: "Actions provided for in part one of this article, committed repeatedly or by prior conspiracy by a group of persons, or on a large scale, or by an official by abuse of office".

Key words: criminal offenses, criminal offenses in the sphere of economic activity, money laundering, misuse of budget funds, implementation of budget expenditures or provision of loans from the budget without established budget allocations or with their excess.

Formulation of the problem in general. One of the biggest threats to the economic, political, social and cultural development of our country has been and still is corruption. The most dangerous type of corruption offenses is corruption offenses. An exhaustive list of these acts is set out in the note to Art. 45 of the Criminal Code of Ukraine. It is important to note that in the Criminal Code of Ukraine, despite the heated scientific discussions, there is no separate section on corruption offenses, as they are part of different types of criminal offenses. In this list of corruption criminal offenses an important place is occupied by criminal offenses in the sphere of economic activity. After all, it is they who, by violating the guarantees of entrepreneurship in the domestic market of the state, cause the weakening of state positions in the political, economic, and military spheres [1, p. 232].

Analysis of recent research and publications. The issue of the legal essence of criminal offenses in the field of economic activity in general, as well as corruption criminal offenses in the field of economic activity in particular, has been studied by such scholars as O. Reznik, V. Sukhonos, V. Bashtannyk, F. Terkhanov, V. Khomenko, I. Gruzina, V. Kudryashov, A. Savchenko, V. Topchiy, T. Suprun and others. At the same time, a comprehensive study on corruption offenses in the field of economic activity was not conducted.

The purpose of the article. That is why we propose to provide a criminal legal characteristic of corruption criminal offenses in the field of economic activity.

Presentation of the main research material. According to Section VII of the Special Part of the Criminal Code of Ukraine, the legislator includes misuse of budget funds, budget expenditures or granting of budget loans without established budget allocations or with their excess (Article 210 of the Criminal Code 
of Ukraine). In general, corruption in budgetary legal relations is the use of the subjects of these relations and participants in the budget process of their official position, the excess of power to illegally enrich both their own and group (collective). It is a question of personal enrichment of the person (group of persons), and also that illegal actions of the official or the official lead to illegal receipt of means on accounts of budgetary institutions, managers and recipients of budgetary funds [2, p. 63]. The generic object of misuse of budget funds, implementation of budget expenditures or provision of loans from the budget without established budget allocations or with their excess is the sphere of economic activity; the main direct object - public relations, ensuring the legitimate functioning of the budget system of Ukraine in terms of spending or lending, and additional direct - the rights and freedoms of citizens, relations in the field of official activities, the authority of public authorities, etc. [3, p. 58].

The budget system is a set of budgets formed on the basis of the administrative-territorial structure of the state and the relationship between them, which are built taking into account the optimal distribution and financial support of state and local authorities between budgets of all levels aimed at socio-economic development [4, p. 27]. Each element of the budget system is relatively independent, on the one hand, and related to other budgets, on the other. Relations between budgets within the budget system are established through regulation through certain mechanisms, including the delineation of sources of income, the use of intergovernmental transfers, the provision of budget loans, and so on [5, p. 732].

The item of the analyzed corruption criminal offense is budget funds, i.e. funds included in the state budget and local budgets, regardless of the source of their formation, in large and especially large amounts [6].

Budget funds are divided into budget revenues and budget expenditures. Budget revenues its revenues, repayment of loans to the budget, funds from state (local) borrowings, funds from privatization of state property (relative to the state budget), return of budget funds from deposits, receipts from the sale/presentation of securities. Budget expenditures its expenditures, granting loans from the budget, debt repayment and placement of budget funds on deposits, purchase of securities [7, p. 123].

The objective side of the analyzed action is the use of state or local budgets contrary to the purpose defined for these funds by the relevant budgets and estimates of revenues and expenditures: 2) the use of budget funds that had a targeted direction, for another purpose, the financing of some expenditures at the expense of other items of expenditure (say, the financing of production at the expense of funds intended for the payment of wages) [8]. A criminal offense, the responsibility for which is provided by Art. 210 of the Criminal Code of Ukraine, is completed from the moment of committing a socially dangerous act, i.e. has a formal composition.

Only an official authorized to dispose of budget funds may be the subject of the analyzed criminal offense. These are primarily responsible officials of enterprises, institutions and budget organizations (managers of budget funds, heads of state executive bodies, heads of departments of ministries, departments, mayors of Kyiv and Sevastopol, regional, district, city state administrations and their deputies, rural, township and mayors, officials of local financial bodies, heads of budgetary institutions). The key point in recognizing a person as a subject of misuse of budget funds, budget expenditures or providing loans from the budget without established budget allocations or with their excess is the presence of authority to dispose of budget funds [7, p. 123]. The subjects of the analyzed criminal offense may also be recognized as officials of legal entities, which, although not directly related to the budget sphere, but use the budget funds received as grants, subsidies or subsidies and spend contrary to the intended purpose. From the subjective point of view, this criminally illegal act can be committed only in the form of direct intent. The legislator understands this act as a financial act transactions or transactions with funds or other property received as a result of viciously dangerous illegal act that preceded the legalization (laundering) of income, as well as actions aimed at concealing or masking illegal origin such funds or other property or possession thereof, rights to such funds or property, relay their origin, location, movement, change of their form (transformation), and the acquisition, possession or use of funds or other property received as a result committing a socially dangerous illegal act that preceded legalization (income) [6]. This crime is characterized by high social danger, because there is a kind of stage of criminal activity and related to corruption, promotes its formation financing and progress; may adversely affect property relations; financial owl-credit system, justice [9].

V. Topchiy, V. Shkelebey and T. Suprun believe that the legislator, who includes only misuse of budget funds, budget expenditures or budget loans without established budget allocations or with their excess, is among the corruption criminal offenses in the sphere of economic activity, that the list of such acts is much wider and to them it is necessary to carry also the actions which are shown in granting of credits and loans for the purpose of their further appropriation (item 209 of Criminal Code of Ukraine) [2, p. 66].

In our opinion, this approach is quite reasonable, because the real money laundering is the fact that this act harms public relations, which provide legal economic activity, violates the principle of equality of economic entities, destroys the basis of honest entrepreneurship based on the law; hinders the implementation of priority-oriented social and economic policy; promotes the creation of uncontrolled monetary and other property funds that could potentially be used to the detriment of society, and stimulates the illegal ("shadow") economy and encourages unjustified property stratification of the population [10]. The corrupt nature of this act is also manifested in the fact that today in Ukraine it is not necessary to use complex transnational systems to legalize (launder) money. Under the auspices of corrupt officials, they can be legalized without resorting to offshore schemes [11, p. 66]. Moreover, in accordance with Art. 13 of the Criminal Convention against Corruption, criminally punishable acts, States parties to the Convention must also recognize the money laundering related to corruption [12]. In addition, the investigation of this offense belongs to the exclusive jurisdiction of National Anti-Corruption Bureau of Ukraine. National Anti-Corruption Bureau of Ukraine, in accordance with the relevant law, is state law enforcement body, which is responsible for preventing, detecting, terminating, investigating and disclosing corruption offenses within its jurisdiction, as well as preventing the commission of new ones. The task of the National Bureau is to counteract criminal corruption offenses committed by senior officials authorized to perform state or local government functions and pose a threat to national security, as well as to take other measures provided by law to combat corruption.

Conclusions. In view of the above, we are convinced that firstly it is necessary to supplement the note to Art. 45 new criminal 
offenses. Secondly, it is necessary to amend Art. 209 of the Criminal Code of Ukraine, supplementing it with the instruction on implementation of the criminally illegal actions specified by $h .1$ by the official by abuse of office. We propose to set out Part 2 of Art. 209 of the Criminal Code of Ukraine in the following wording: "Actions provided for in part one of this article, committed repeatedly or by prior conspiracy by a group of persons, or on a large scale, or by an official by abuse of office".

\section{References:}

1. Рєзнік О.М. Порівняльний аналіз сутності економічної безпеки України та країн Європейського Союзу. Форум права. 2015. № 4. С. 232-236.

2. Топчій В.В., Шкелебей В.А., Супрун Т.М. Публічно-правова протидія корупції : навчальний посібник. Вінниця : ТОВ «НіланЛТД», 2016. 208 c.

3. Савченко А.В. Корупційні злочини (кримінально-правова характеристика) : навчальний посібник. Київ : «Центр учбової літератури», 2016. $168 \mathrm{c}$.

4. Кудряшов В.П. Поняття бюджетної системи та ії децентралізації. Фінанси Украӥни. 2011. № 8. С. 25-32.

5. Грузіна I.А. Сутність та складники бюджетної системи. Молодий вчений. 2016. № 12. С. 730-733.

6. Кримінальний кодекс України від 05 квіт. 2001 р. № 2341-ІІІ. Вiдомості Верховної Ради України (ВВР). 2001. № 25-26. Ст. 131.

7. Хоменко В.П. Кримінальна відповідальність за нецільове використання бюджетних коштів, здійснення видатків бюджету чи надання кредитів із бюджету без встановлених бюджетних призначень або з їх перевищенням. Науковий вісник Національної академії внутрішніх справ. 2016. № 1. С. 120-132.

8. Науково-практичний коментар до КК України. URL: http:// pravoznavec.com/ua/books/162/12264/28/ (дата звернення: 28.10.2020).

9. Рєзнік О.М., Бондаренко О.С. Кримінально-правова характеристика об'єктивних ознак легалізації (відмивання) доходів, одержаних злочинним шляхом. Право $і$ суспільство. 2020. № 2. Ч. 3. С. 133-139.

10. Баштанник В.В., Терханов Ф.І. Удосконалення державного управління у сфері протидії легалізації доходів, отриманих злочинним шляхом. URL: http://www. dridu. dp. ua/zbirnik/2011-02 (6)/11bvvozs. Pdf (дата звернення: 10.02.2021).

11. Сухонос В.В. Корупція як складник способів легалізації доходів, одержаних злочинним шляхом. Правові горизонти. 2017. Вип. 7(20). С. 63-71.

12. Criminal Law Convention on Corruption on 27 January 1999. URL: https://rm.coe.int/168007f3f5 (дата звернення: 26.10.2020).

Бондаренко О. Кримінально-правова характеристика корупційних кримінальних правопорушень у сфері господарської діяльності

Анотація. Стаття присвячена важливій та актуальній темі - кримінально-правовій характеристиці корупційних кримінальних правопорушень у сфері господарської діяльності. Автор наголошує, що корупція $є$ згубним соціально-економічним явищем. Найбільш небезпечними ії проявами є саме корупційні кримінальні правопорушення. Класифікувати корупційні кримінальні правопорушення можливо за кількома критеріями. Один із них - це родовий об'єкт складу кримінального правопорушення. На основі цього критерію можна виокремити корупційні кримінальні правопорушення у сфері господарської діяльності. 3 числа злочинів у сфері господарської діяльності законодавець у примітці до ст. 45 Кримінального кодексу України називає корупційним лише нецільове використання бюджетних коштів, здійснення видатків бюджету чи надання кредитів з бюджету без встановлених бюджетних призначень або з їх перевищенням (ст. 210 Кримінального кодексу України).

Родовим об'єктом цього правопорушення є суспільні відносини, які забезпечують правомірне функціонування бюджетної системи стосовно витрат або кредитів та додаткових прямих прав і свобод громадян, відносин у сфері службової діяльності, повноважень органів влади тощо. Предметом аналізованого злочинного діяння $€$ бюджетні кошти, тобто кошти, які незалежно від джерела їх походження містяться у великих та особливо великих обсягах у державному та місцевих бюджетах. Об'єктивною стороною аналізованого корупційного кримінального правопорушення $\epsilon$ використання державного або місцевих бюджетів, що суперечить цілі, встановленій для цих бюджетів відповідними бюджетами та кошторисами доходів і витрат.

Суб'єктом нецільового використання бюджетних коштів, здійснення видатків бюджету чи надання кредитів 3 бюджету без встановлених бюджетних призначень або 3 їх перевищенням може бути лише службова особа, яка має право розпоряджатися бюджетними ресурсами. Це насамперед відповідальні службові особи підприємств, установ та бюджетних організацій (розпорядники бюджетних коштів, керівники державних органів виконавчої влади, керівники міністерств, відомств). Із суб'єктивної точки зору це злочинне діяння може бути вчинене лише у формі прямого умислу.

На відміну від законодавця, який серед корупційних кримінальних правопорушень у сфері господарської діяльності виділяє нецільове використання бюджетних коштів, здійснення видатків бюджету чи надання кредитів з бюджету без встановлених бюджетних призначень або 3 їх перевищенням, ми вважаємо, що перелік таких діянь ширший. Сюди входить і легалізація (відмивання) доходів, одержаних злочинним шляхом.

На підставі здійсненого аналізу робиться висновок про необхідність доповнення примітки до ст. 45 новим кримінальним правопорушенням. А також оновлення тексту ст. 209 Кримінального кодексу України шляхом прямої вказівки на реалізацію вказаних у ч. 1 кримінально протиправних дій службовою особою шляхом зловживання службовим становищем.

Ключові слова: кримінальні правопорушення, кримінальні правопорушення у сфері господарської діяльності, легалізація доходів, одержаних злочинним шляхом, нецільове використання бюджетних коштів, здійснення видатків бюджету чи надання кредитів 3 бюджету без встановлених бюджетних призначень або 3 їх перевищенням. 